\title{
Chemical microenvironments and single-cell carbon and nitrogen uptake in field-collected colonies of Trichodesmium under different $\mathrm{pCO}_{2}$
}

\author{
Meri J Eichner ${ }^{1,6}$, Isabell Klawonn ${ }^{2,7}$, Samuel T Wilson ${ }^{3}$, Sten Littmann ${ }^{4}$, \\ Martin J Whitehouse ${ }^{5}$, Matthew J Church ${ }^{3}$, Marcel MM Kuypers ${ }^{4}$, David M Karl ${ }^{3}$ \\ and Helle Ploug ${ }^{1}$ \\ ${ }^{1}$ Department of Marine Sciences, University of Gothenburg, Gothenburg, Sweden; ${ }^{2}$ Department of Ecology, \\ Environment and Plant Sciences, University of Stockholm, Stockholm, Sweden; ${ }^{3}$ Daniel K. Inouye Center for \\ Microbial Oceanography: Research and Education, University of Hawaii, Honolulu, HI, USA; ${ }^{4}$ Department of \\ Biogeochemistry, Max Planck Institute for Marine Microbiology, Bremen, Germany and ${ }^{5}$ Department of \\ Geosciences, Swedish Museum of Natural History, Stockholm, Sweden
}

\begin{abstract}
Gradients of oxygen $\left(\mathrm{O}_{2}\right)$ and $\mathrm{pH}$, as well as small-scale fluxes of carbon (C), nitrogen (N) and $\mathrm{O}_{2}$ were investigated under different partial pressures of carbon dioxide $\left(p \mathrm{CO}_{2}\right)$ in field-collected colonies of the marine dinitrogen $\left(\mathrm{N}_{2}\right)$-fixing cyanobacterium Trichodesmium. Microsensor measurements indicated that cells within colonies experienced large fluctuations in $\mathrm{O}_{2}, \mathrm{pH}$ and $\mathrm{CO}_{2}$ concentrations over a day-night cycle. $\mathrm{O}_{2}$ concentrations varied with light intensity and time of day, yet colonies exposed to light were supersaturated with $\mathrm{O}_{2}$ (up to $\sim 200 \%$ ) throughout the light period and anoxia was not detected. Alternating between light and dark conditions caused a variation in pH levels by on average 0.5 units (equivalent to $15 \mathrm{nmol} \mathrm{I}^{-1}$ proton concentration). Single-cell analyses of $\mathrm{C}$ and $\mathrm{N}$ assimilation using secondary ion mass spectrometry (SIMS; large geometry SIMS and nanoscale SIMS) revealed high variability in metabolic activity of single cells and trichomes of Trichodesmium, and indicated transfer of $\mathrm{C}$ and $\mathrm{N}$ to colony-associated non-photosynthetic bacteria. Neither $\mathrm{O}_{2}$ fluxes nor $\mathrm{C}$ fixation by Trichodesmium were significantly influenced by short-term incubations under different $p \mathrm{CO}_{2}$ levels, whereas $\mathrm{N}_{2}$ fixation increased with increasing $p \mathrm{CO}_{2}$. The large range of metabolic rates observed at the single-cell level may reflect a response by colony-forming microbial populations to highly variable microenvironments.
\end{abstract}

The ISME Journal (2017) 11, 1305-1317; doi:10.1038/ismej.2017.15; published online 11 April 2017

\section{Introduction}

The biological fixation of dinitrogen $\left(\mathrm{N}_{2}\right)$ into ammonia by marine cyanobacteria has a crucial role in fueling primary production and material export in the oligotrophic open ocean (Karl et al., 1997, 2008). In the North Pacific Subtropical Gyre, $\mathrm{N}_{2}$ fixation has been estimated to support up to $50 \%$ of export production (Dore et al., 2002; Böttjer et al., 2017). A key contribution to the pool of fixed nitrogen $(\mathrm{N})$ is provided by Trichodesmium sp., a filamentous, colony-forming, non-heterocystous cyanobacterium known for forming vast near-

Correspondence: MJ Eichner, Max Planck Institute for Marine Microbiology, Celsiusstr. 1, Bremen 28359, Germany.

E-mail: meichner@mpi-bremen.de

${ }^{6}$ Current address: Max Planck Institute for Marine Microbiology, Bremen, Germany.

${ }^{7}$ Current address: Leibnitz Institute of Freshwater Ecology and Inland Fisheries (IGB), Berlin, Germany.

Received 21 September 2016; revised 19 December 2016; accepted

9 January 2017; published online 11 April 2017 surface blooms throughout the tropical and subtropical oceans (LaRoche and Breitbarth, 2005). Observations of elevated concentrations of ammonium and dissolved organic $\mathrm{N}$ within Trichodesmium blooms (Karl et al., 1992), and significant release of fixed $\mathrm{N}$ by Trichodesmium in laboratory and field studies (Mulholland, 2007) suggest that this diazotroph is an important source of new $\mathrm{N}$ to its associated community. Understanding the ecology and physiology of this keystone species has been complicated by its patchy distribution in the water column, occurrence as single trichomes and colonies in highly variable contributions (Letelier and Karl, 1996; Carpenter et al., 2004) and its substantial epibiota (Siddiqui et al., 1992; Sheridan et al., 2002; Hewson et al., 2009; Hmelo et al., 2012; Momper et al., 2015). Furthermore, the ability of Trichodesmium to fix $\mathrm{N}_{2}$ during daytime, when it conducts oxygenic photosynthesis, remains enigmatic, as the $\mathrm{N}_{2}$-fixing enzyme nitrogenase is inhibited by oxygen $\left(\mathrm{O}_{2}\right)$ both in vitro and in vivo (Gallon, 1992; Burgess and Lowe, 1996; Durner 
et al., 1996; Staal et al., 2007). It was previously considered that $\mathrm{O}_{2}$-depleted microzones in Trichodesmium colonies shielded nitrogenase from $\mathrm{O}_{2}$ and thereby facilitated $\mathrm{N}_{2}$ fixation (for example, Carpenter and Price, 1976; Paerl and Bebout, 1988). Additional $\mathrm{O}_{2}$ protection mechanisms include the confinement of nitrogenase to specialized cells within trichomes termed diazocytes (Bergman and Carpenter, 1991; Fredriksson and Bergman, 1995), and the downregulation of photosynthesis during the period of maximum nitrogenase activity at midday (Berman-Frank et al., 2001). Although these proposed mechanisms help explain how Trichodesmium can simultaneously fix $\mathrm{N}_{2}$ and photosynthesize without heterocysts, many questions remain as to the short-term regulation of these processes in single trichomes and colonies (for example, Bergman et al., 2013).

Application of microsensor technology to analyze small-scale chemical gradients has highlighted the influence of photosynthesis and respiration on $\mathrm{O}_{2}$ and $\mathrm{pH}$ microenvironments in Baltic cyanobacterial aggregates (Ploug, 2008). Similar measurements also showed that Trichodesmium colonies can establish and sustain $\mathrm{O}_{2}$ microenvironments, which are distinct from the ambient water (Paerl and Bebout, 1988). Colony microenvironments are also relevant to carbonate chemistry, as model calculations suggest that partial pressure of carbon dioxide $\left(p \mathrm{CO}_{2}\right)$ in the diffusive boundary layer of phytoplankton cells differs substantially from the ambient water (Wolf-Gladrow et al., 1999; Flynn et al., 2012). In a laboratory study simulating a Trichodesmium bloom, strong deviations in carbonate chemistry were observed, inducing precipitation of calcium carbonate (Kranz et al., 2010b).

The responses of Trichodesmium to predicted future climate change have been investigated in a range of laboratory and field studies with varying results, including both strong positive responses (for example, Hutchins et al., 2007; Levitan et al., 2007; Kranz et al., 2009) and no responses to elevated seawater $p \mathrm{CO}_{2}$ (lower $\mathrm{pH}$ ) scenarios (for example, Böttjer et al., 2014; Gradoville et al., 2014). Interactions of $\mathrm{CO}_{2}$ effects on Trichodesmium with other environmental factors, such as light and nutrients (Kranz et al., 2010a; Shi et al., 2012), suggest that distinct microenvironments in Trichodesmium colonies may influence its $\mathrm{CO}_{2}$ responses.

Here, we characterized $\mathrm{O}_{2}$ and $\mathrm{pH}$ gradients within and around Trichodesmium colonies collected in the North Pacific Subtropical Gyre using microsensors. In addition, secondary ion mass spectrometry (SIMS) was used to quantify the uptake of carbon (C) and $N$ on the single-cell level and to track its fate in these colonies. We discuss the implications of colony formation for key physiological processes in Trichodesmium, as well as potential consequences for its responses to ocean acidification.

\section{Materials and methods}

Trichodesmium and seawater sampling

Experiments were conducted at Station ALOHA $\left(22^{\circ}\right.$ $45^{\prime} \mathrm{N} 158^{\circ} 00^{\prime} \mathrm{W}$ ) in the oligotrophic North Pacific Subtropical Gyre in September 2014 on board R/V Kilo Moana (HOT Cruise 265). Trichodesmium colonies were sampled from the near-surface ocean (a depth of $<10 \mathrm{~m}$, unless otherwise specified, Supplementary Table S1) using a hand-held plankton net $(200 \mu \mathrm{m}$ mesh). Individual colonies (puffshaped if not specified differently) for stable isotope incubations and microsensor measurements were picked with an inoculation loop and transferred into filtered $(0.2 \mu \mathrm{m})$ seawater collected at Station ALOHA. Additional colonies for microsensor measurements (as specified in Supplementary Table S1) were sampled from coastal surface waters $\left(21^{\circ} 15^{\prime} \mathrm{N}\right.$ $157^{\circ} 49^{\prime} \mathrm{W}$ ) and brought to the laboratory within $1 \mathrm{~h}$ of collection.

\section{Carbonate chemistry}

To manipulate carbonate chemistry, seawater was bubbled with gas mixtures of different $p \mathrm{CO}_{2}$ levels and allowed to equilibrate at $25^{\circ} \mathrm{C}$ for $>12 \mathrm{~h}$. For the ambient $p \mathrm{CO}_{2}$ treatment, room air was supplied by aquarium pumps, yielding a $p \mathrm{CO}_{2}$ of $506 \pm 128 \mu \mathrm{atm}$ and $\mathrm{pH}_{\mathrm{NBS}}$ (US National Bureau of Standards (NBS) scale) of $8.1 \pm 0.1$ (Supplementary Table S2). For the high $\mathrm{pCO}_{2}$ treatment, a mixture of ambient air and $\mathrm{CO}_{2}$ (Scott Specialty Gases, Fremont, CA, USA; purity $99.995 \%$ ) was prepared with a gas mixing pump (Westhoeff, Bochum, Germany), yielding a $\mathrm{pCO}_{2}$ of $1117 \pm 358 \mu \mathrm{atm}$ and $\mathrm{pH}_{\mathrm{NBS}}$ of $7.8 \pm 0.1$. $\mathrm{pH}$ levels were measured with a microelectrode (Unisense, Aarhus, Denmark) that was two-point calibrated with NBS buffers (Sigma Aldrich, Stockholm, Sweden). Samples for dissolved inorganic C (DIC) and total alkalinity (TA) were filtered (0.2 and $0.45 \mu \mathrm{m}$ polycarbonate filters, respectively) and fixed with mercuric chloride. DIC was measured colorimetrically (QuAAtro autoanalyzer, Seal, Norderstedt, Germany). TA was determined by potentiometric titration (TitroLine alpha plus, Schott Instruments, Mainz, Germany). DIC, TA and $\mathrm{pH}_{\mathrm{NBS}}$ in the experimental system were monitored on a daily basis (Supplementary Table S2).

\section{Colony characteristics}

Individual Trichodesmium colonies for cell counts (using microscopes Eclipse 90i, Nikon Instruments, Düsseldorf, Germany/Axiovert 135, Zeiss, Jena, Germany) were preserved in Lugol's solution (Sigma Aldrich). To quantify the number of cells per colony, the cumulative length of all trichomes in a colony was divided by the average cell length. Samples for analysis of species composition were coated with $0.1 \%$ agarose and stained with 4,6-diamidino-2phenylindole before epi-fluorescence microscopy 
(Axioplan2 imaging, Zeiss). Trichodesmium species were identified based on cell shape and size following Hynes et al. (2012). For quantification of chl $a$ concentrations, 15 colonies per replicate were collected on glass fiber filters $(25 \mathrm{~mm}$ diameter, Whatman, Maidstone, UK), and the chl $a$ extracted in $5 \mathrm{ml}$ of $90 \%$ acetone at $-20^{\circ} \mathrm{C}$ before fluorometric analysis (Turner Designs 10-AU, Sunnyvale, CA, USA; Strickland and Parsons, 1972). For determination of particulate organic $\mathrm{C}$ and $\mathrm{N}$ (POC and PON) contents, as well as dry weight, 15-25 colonies per replicate were collected on pre-combusted glass fiber filters (25 mm, Whatman). Before mass spectrometry (ThermoFinnigan DeltaXP, Bremen, Germany), filters were acidified ( $\mathrm{HCl}$ fume, $>12 \mathrm{~h}$ ) and dehydrated $\left(50^{\circ} \mathrm{C},>12 \mathrm{~h}\right)$.

\section{Microsensor measurements}

Microsensor measurements of $\mathrm{O}_{2}$ concentrations and $\mathrm{pH}$ in colonies were conducted in a custom-made flow system (Ploug and Jørgensen, 1999), where colonies were suspended in a laminar flow $\left(0.1 \mathrm{~mm} \mathrm{~s}^{-1}\right)$ of filtered seawater with stable $\mathrm{O}_{2}$ concentrations and $\mathrm{pH}$ levels. For determining gradients within and surrounding the colonies, the microelectrode was carefully advanced toward and through the colony as observed under a dissection microscope. Measurements were conducted with a Clark-type $\mathrm{O}_{2}$ microelectrode $(10 \mu \mathrm{m}$ tip size; response time 1-3 s; Unisense) and a pH microelectrode $(100 \mu \mathrm{m}$ tip size, response time $<10 \mathrm{~s}$; Unisense). Seawater in the flow system was continuously bubbled with air of the respective $p \mathrm{CO}_{2}$ and the resulting $p \mathrm{CO}_{2}$ and $\mathrm{pH}_{\mathrm{NBS}}$ values were confirmed as described above (section 'Carbonate chemistry'). Colonies were pre-incubated at the respective $\mathrm{pCO}_{2}$ for $2-6.5 \mathrm{~h}$ in an on-deck incubator and subsequently acclimatized to conditions in the flow system for $\sim 10 \mathrm{~min}$. Measurements were performed at $25^{\circ} \mathrm{C}$ and $1000 \mu \mathrm{mol}$ photons $\mathrm{m}^{-2} \mathrm{~s}^{-1}$ unless specified otherwise (cold-white halogen lamps (5500 K), VWR International, Stockholm, Sweden).

Net community $\mathrm{O}_{2}$ fluxes (J) in light and dark were calculated from the steady-state $\mathrm{O}_{2}$ gradients at the colony surface (dC/dr) according to Fick's first law of diffusion, applying a diffusion coefficient (D) of $2.2593 \times 10^{-5} \mathrm{~cm}^{2} \mathrm{~s}^{-1}$ for $\mathrm{O}_{2}\left(25^{\circ} \mathrm{C}\right.$, salinity 34 ; Broecker and Peng, 1974):

$J=-D \frac{d C}{d r}$

Colony surface area and volume for normalization were calculated from measured half axes assuming ellipsoid geometry. $\mathrm{O}_{2}$ residence time in colonies was estimated from the initial decrease in $\mathrm{O}_{2}$ concentrations at the colony surface following a light to dark shift (Jørgensen and Revsbech, 1985).
Stable isotope incubations

To measure rates of $\mathrm{C}$ and $\mathrm{N}_{2}$ fixation, single Trichodesmium colonies were incubated with ${ }^{15} \mathrm{~N}_{2}$ gas (Cambridge Isotope Laboratories, Tewksbury, MA, USA) and $\mathrm{NaH}^{13} \mathrm{CO}_{3}$ (Sigma Aldrich) in $5.9 \mathrm{ml}$ vials (Exetainer, Labco, Lampeter, UK) at the respective $p \mathrm{CO}_{2}$ level. Solutions of ${ }^{15} \mathrm{~N}_{2}$ gas and $\mathrm{NaH}^{13} \mathrm{CO}_{3}$ in filtered seawater were prepared according to Klawonn et al. (2015b). The atom percent excess (AT\% excess) for ${ }^{13} \mathrm{C}$ at the beginning of incubations was $4.2 \pm 0.2$ (ambient $p \mathrm{CO}_{2}$ ) and $3.8 \pm 0.1$ (high $p \mathrm{CO}_{2}$; quantified by gas chromatography isotope ratio mass spectrometry; $n=6$ ). The AT $\%$ excess for ${ }^{15} \mathrm{~N}$ was $4.2 \pm 0.4$ (ambient $p \mathrm{CO}_{2}$ ) and $3.5 \pm 0.3$ (high $p \mathrm{CO}_{2}$; quantified by membrane inlet mass spectrometry; $n=7$ ). Day and night incubations were conducted for $11.5 \mathrm{~h}$, respectively, in an ondeck incubator shaded to $50 \%$ surface irradiance (blue acrylic shielding \#2069, Delvie's Plastic Inc., Salt Lake City, UT, USA) at sea-surface temperature, allowing for gentle movement of the vials to minimize diffusion limitation to the colonies. Subsequent to incubations, colonies were fixed with paraformaldehyde ( $2 \%$ final concentration; Electron Microscopy Sciences, Hatfield, PA, USA) for $24 \mathrm{~h}$ at $4{ }^{\circ} \mathrm{C}$ in darkness, filtered onto polycarbonate filters (type GTTP, $0.2 \mu \mathrm{m}$, Millipore, Merck, Darmstadt, Germany), washed with milliQ water and stored at room temperature.

\section{Secondary ion mass spectrometry}

After incubation with stable isotope tracers, isotopic composition of single cells was analyzed by large geometry SIMS (LG-SIMS; IMS1280, CAMECA, Gennevilliers, France) and nanoscale SIMS (nanoSIMS; nanoSIMS 50 L, CAMECA). LG-SIMS provides a higher throughput than nanoSIMS and was chosen for obtaining a large number of measurements on single Trichodesmium cells. The higher resolution measurements necessary for analyzing the enrichment of associated bacteria were performed by nanoSIMS.

A total of 66-135 Trichodesmium cells per treatment were analyzed by LG-SIMS, ensuring that mean values were stable and representative for the population (as described in Svedén et al. 2015). Filters with sample material were gold coated before measurements. Measurements were performed using a cesium ion $\left(\mathrm{Cs}^{+}\right)$primary beam with a spatial resolution of $1 \mu \mathrm{m}$. Areas of interest $(90 \times 90 \mu \mathrm{m})$ were pre-sputtered with a beam of $3 \mathrm{nA}(100 \mathrm{~s})$ and then imaged using a 40-60 pA primary beam for 100 cycles. Secondary ion images of ${ }^{13} \mathrm{C}^{14} \mathrm{~N}^{-},{ }^{12} \mathrm{C}^{14} \mathrm{~N}^{-}$and ${ }^{12} \mathrm{C}^{15} \mathrm{~N}^{-}$were recorded using a peak-switching routine at a mass resolution of ca. $6000(\mathrm{M} / \Delta \mathrm{M})$. Selection of regions of interest (corresponding to single cells) and subsequent data analysis were performed using the WinImage 2 software (CAMECA). Trichome morphology was additionally 
analyzed by epi-fluorescence microscopy (Axioplan2 imaging, Zeiss).

Using nanoSIMS, 51-65 associated bacteria and 28-42 additional Trichodesmium cells were analyzed for each treatment in a subsample of one of the colonies analyzed previously by LG-SIMS. Subsequent to 4,6-diamidino-2-phenylindole staining and gold coating of the filters, associated bacteria attached to or positioned next to Trichodesmium cells on the filters were selected by fluorescence microscopy and marked by Laser Microdissection Microscopy (LMD6000, Leica, Wetzlar, Germany). The marked areas of interest were imaged by scanning electron microscopy (Quanta 250 FEG, FEI, Hillsboro, OR, USA). Secondary electron images were taken under high vacuum conditions using an Everhart-Thornley detector with an acceleration voltage of $2 \mathrm{kV}$ for the electron beam. For nanoSIMS measurements, the areas were pre-sputtered with a $\mathrm{Cs}^{+}$primary ion beam of $\sim 100 \mathrm{pA}$. During nanoSIMS analysis, the $\mathrm{Cs}^{+}$ion beam was focused to a nominal spot size of $<100 \mathrm{~nm}$ in diameter and a beam current of 0.8$1.2 \mathrm{pA}$ was used. Secondary ion images for ${ }^{12} \mathrm{C}^{-}$, ${ }^{13} \mathrm{C}^{-},{ }^{12} \mathrm{C}^{14} \mathrm{~N}^{-}$and ${ }^{12} \mathrm{C}^{15} \mathrm{~N}^{-}$were simultaneously recorded. To minimize interferences, the instrument was tuned with an average mass resolution of $>8000 \mathrm{M} / \Delta \mathrm{M}$. Selection of regions of interest and subsequent data analysis were performed using the Look@nanosims software (Polerecky et al., 2012).

$\mathrm{C}$ and $\mathrm{N}_{2}$ fixation by Trichodesmium are presented as C- and $\mathrm{N}$-specific fixation rates, respectively, which reflect cellular turnover of $\mathrm{C}$ through C-fixation and turnover of $\mathrm{N}$ through $\mathrm{N}_{2}$ fixation. These values are equivalent to $\mathrm{C}$ - and $\mathrm{N}$-based growth rates and are independent of cell size. Specific C and N fixation of Trichodesmium were calculated from AT $\%$ in the cell $\left(\mathrm{AT} \% \%_{\text {cell }}\right)$ and on the filter background $\left(\mathrm{AT} \% \%_{\mathrm{bg}}\right), \mathrm{AT} \%$ excess of the total dissolved $\mathrm{N}_{2}$ or DIC pool in the ambient water (measured as described above ('Stable isotope incubations'; AT\% excess $_{\text {ambient }}$ ) and the incubation time (dt) as follows (adapted from Montoya et al., 1996):

specific fixation $\left[h^{-1}\right]=\frac{\mathrm{AT} \%_{\text {cell }}-\mathrm{AT} \%_{b g}}{\mathrm{AT} \text { excess }_{\text {ambient }} \times \mathrm{dt}}$

\section{Results}

Trichodesmium colony characteristics

Colonies of Trichodesmium varied strongly in size (100-800 $\mu \mathrm{m}$ half axes), as well as in cell numbers per colony volume $\left(R^{2}<0.1\right.$, ordinary least squares linear regression of cell number vs colony volume; Table 1). Although colony POC and PON contents were variable (Table 1), the ratio of POC:PON was relatively constant at $5.7 \pm 0.8$ (mol:mol; $n=13$ ). Single colonies appeared to consist of multiple species tentatively identified as Trichodesmium
Table 1 Key characteristics of Trichodesmium colonies sampled during the experiment (mean \pm s.d.)

\begin{tabular}{lcc}
\hline Parameter & Unit & Value \\
\hline Cells & Colony $^{-1}$ & $5946 \pm 6852(n=22)$ \\
Trichomes & Colony $^{-1}$ & $76 \pm 63(n=22)$ \\
Volume & $\mathrm{mm}^{3}$ colony $^{-1}$ & $0.17 \pm 0.19(n=14)$ \\
Half axis & $\mu \mathrm{m}$ & $323 \pm 106(n=14)$ \\
Dry weight & $\mu$ colony $^{-1}$ & $448 \pm 175(n=22)$ \\
Chl $a$ & ng colony $^{-1}$ & $14 \pm 4(n=5)$ \\
POC & $\mu$ colony $^{-1}$ & $3.7 \pm 1.5(n=12)$ \\
PON & $\mu$ colony $^{-1}$ & $0.5 \pm 0.2(n=12)$ \\
\hline
\end{tabular}

Abbreviations: POC, particulate organic carbon; PON, particulate organic nitrogen.

erythraeum, Trichodesmium thiebautii and Trichodesmium tenue (Figure 1, Supplementary Table S3). Associated bacteria occurred primarily as single cells, but also included short filaments of $2-5$ cells and did not show chlorophyll autofluorescence under blue light (488 $\mathrm{nm}$ ) excitation (Figure 1).

\section{Microenvironments and $\mathrm{O}_{2}$ fluxes}

Microsensor measurements revealed steep gradients in $\mathrm{O}_{2}$ concentrations and $\mathrm{pH}$ associated with Trichodesmium colonies (Figures 2a and b). Repeated measurements on individual colonies in the light showed that net $\mathrm{O}_{2}$ production of the microbial community was dependent on the time of day, with a decrease in $\mathrm{O}_{2}$ concentrations within colonies toward noon, followed by an increase toward the afternoon and a decrease in the evening (Figure 2d). After sunset (20:00 hours), colonies were undersaturated with $\mathrm{O}_{2}$ in both light and dark conditions, but anoxic conditions were not detected (Figure 2d). During daytime, $\mathrm{O}_{2}$ concentrations were also dependent on light intensity (Figure 2c). Across all colonies and treatments, $\mathrm{O}_{2}$ saturation varied between $61 \%$ and $203 \%$ (relative to air-saturated seawater, $\left.25^{\circ} \mathrm{C}, 34 \mathrm{psu}\right)$. When exposed to light, $\mathrm{O}_{2}$ saturation in the colony center was $153 \pm 29 \%$ and $128 \pm 41 \%$ for ambient and high $p \mathrm{CO}_{2}$, respectively (Figure 3). In the dark, mean $\mathrm{O}_{2}$ saturation in the center of colonies was $79 \pm 10 \%$ and $75 \pm 5 \%$ for ambient and high $p \mathrm{CO}_{2}$, respectively (Figure 3). Although net $\mathrm{O}_{2}$ production and dark respiration within colonies (Table 2) were highly correlated $\left(R^{2}=0.86\right)$, weak correlation of $\mathrm{O}_{2}$ fluxes with colony radius $\left(R^{2}<0.53\right)$ reflected variability in the abundance and composition of organisms in colonies. Dark respiration was equivalent to $35 \pm 12 \%(n=8)$ of gross $\mathrm{O}_{2}$ production (that is, the sum of net $\mathrm{O}_{2}$ production and dark respiration), with $\mathrm{O}_{2}$ residence time within colonies averaging $1.8 \pm 0.9 \mathrm{~min}(n=9)$. Differences in the $p \mathrm{CO}_{2}$ treatments affected neither $\mathrm{O}_{2}$ concentrations in the center of colonies ( $t$-test, $P>0.05$; Figure 3 ) nor $\mathrm{O}_{2}$ fluxes ( $t$-test, $P>0.05$; Table 2).

$\mathrm{pH}_{\mathrm{NBS}}$ in the center of colonies ranged from 7.2 to 8.8. In the light, mean $\mathrm{pH}_{\mathrm{NBS}}$ levels in the center of 


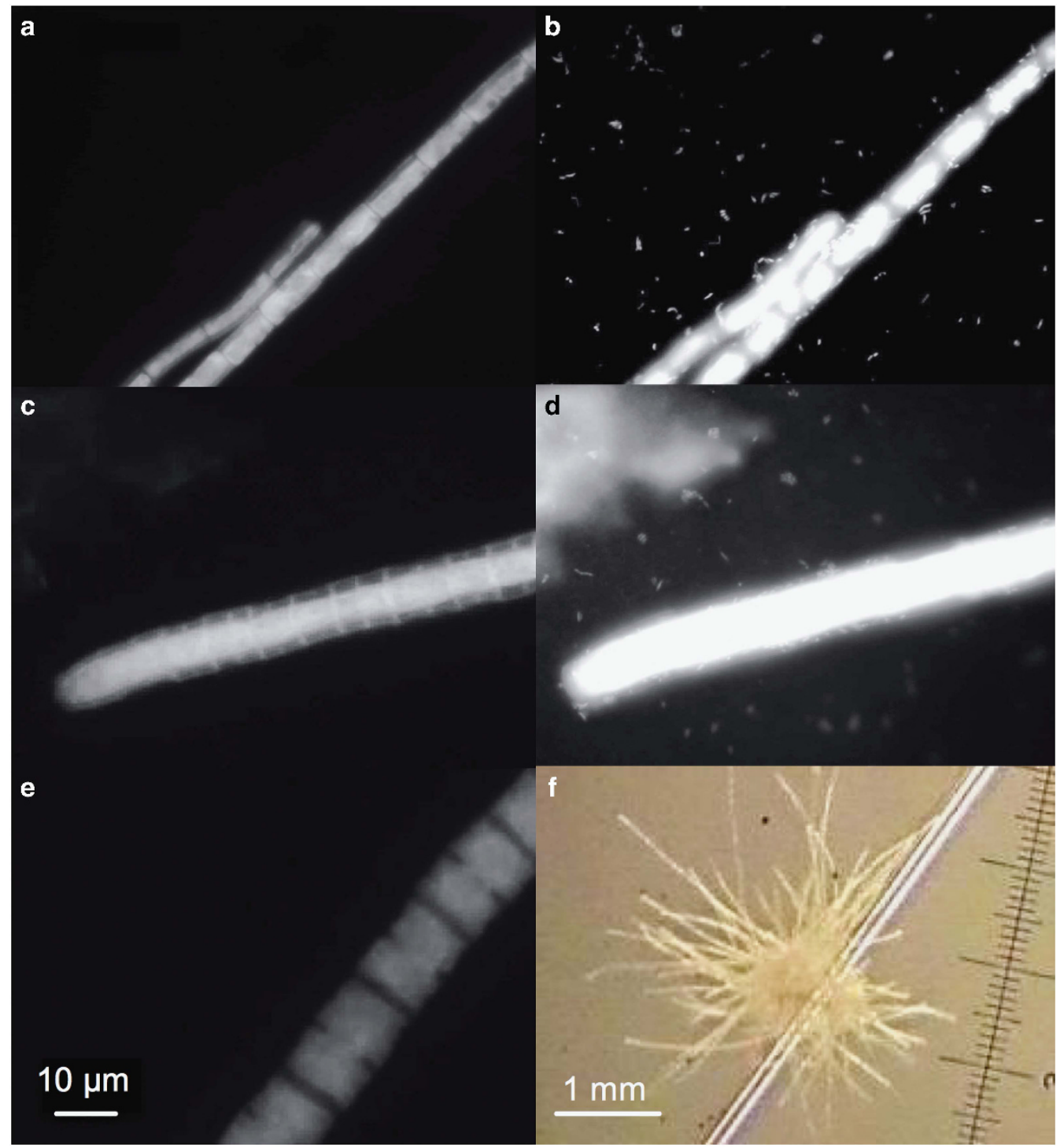

Figure 1 Morphology of Trichodesmium and associated bacteria. (a, c, e) show chlorophyll autofluorescence; (b, d) show 4,6-diamidino2-phenylindole (DAPI) staining. (a, b) trichome type I (trichome on the left) and II (trichome on the right); (c, d) trichome type III; (e) trichome type IV ( $c f$. Supplementary Table S3). Scale bar in e is valid for a through e. (f) Typical morphology of a puff-shaped colony.

colonies were $8.4 \pm 0.2$ at ambient $\mathrm{pCO}_{2}$ (mean $\mathrm{pH}$ in surrounding seawater 8.1 ) and $8.0 \pm 0.3$ at high $p \mathrm{CO}_{2}$ (mean $\mathrm{pH}$ in surrounding seawater 7.8; Figure 3). In the dark, $\mathrm{pH}_{\mathrm{NBS}}$ levels in the center of colonies were $7.8 \pm 0.2$ and $7.6 \pm 0.2$ under ambient and high $p \mathrm{CO}_{2}$, respectively. The respective proton concentrations were $5 \pm 3 \mathrm{nmoll}^{-1}$ (ambient $p \mathrm{CO}_{2}$ ) and $12 \pm 7 \mathrm{nmoll}^{-1}$ (high $p \mathrm{CO}_{2}$ ) in light, and $17 \pm 9 \mathrm{nmol} \mathrm{l}^{-1}$ (ambient $p \mathrm{CO}_{2}$ ) and $31 \pm 19 \mathrm{nmoll}^{-1}$ (high $\mathrm{pCO}_{2}$ ) in dark conditions (Figure 3 ).

\section{$\mathrm{C}$ and $\mathrm{N}_{2}$ fixation}

$\mathrm{C}$ and $\mathrm{N}_{2}$ fixation were highly variable between individual Trichodesmium cells (Figure 4). Variation was higher between cells in different trichomes than within single trichomes. ${ }^{15} \mathrm{~N}$ enrichment for cells incubated during the day ranged up to $0.75 \mathrm{AT} \%$ excess, equivalent to $\mathrm{N}$-specific $\mathrm{N}$ fixation rates of up to $0.015 \mathrm{~h}^{-1}$. C and $\mathrm{N}_{2}$ fixation rates measured during night-time were similar to controls (that is, Trichodesmium colonies with no label added) in both $p \mathrm{CO}_{2}$ treatments (Table 3). Interestingly, several trichomes showed very low ${ }^{15} \mathrm{~N}$ enrichment during daytime (equivalent to $\mathrm{N}$-specific $\mathrm{N}$ fixation $<0.0025 \mathrm{~h}^{-1}$ ) although they were highly enriched in ${ }^{13} \mathrm{C}$ relative to controls (approximately 25\% of cells analyzed; for example, green squares (trichome \#1), Figure 4). The reverse, that is, ${ }^{15} \mathrm{~N}$ enrichment in the absence of ${ }^{13} \mathrm{C}$ enrichment occurred only in 3 out of the 320 cells analyzed. No consistent patterns in ${ }^{13} \mathrm{C}$ and ${ }^{15} \mathrm{~N}$ enrichment depending on trichome width and length were observed (data not shown). $\mathrm{C}$ and $\mathrm{N}_{2}$ fixation rates varied depending on cellular position within 

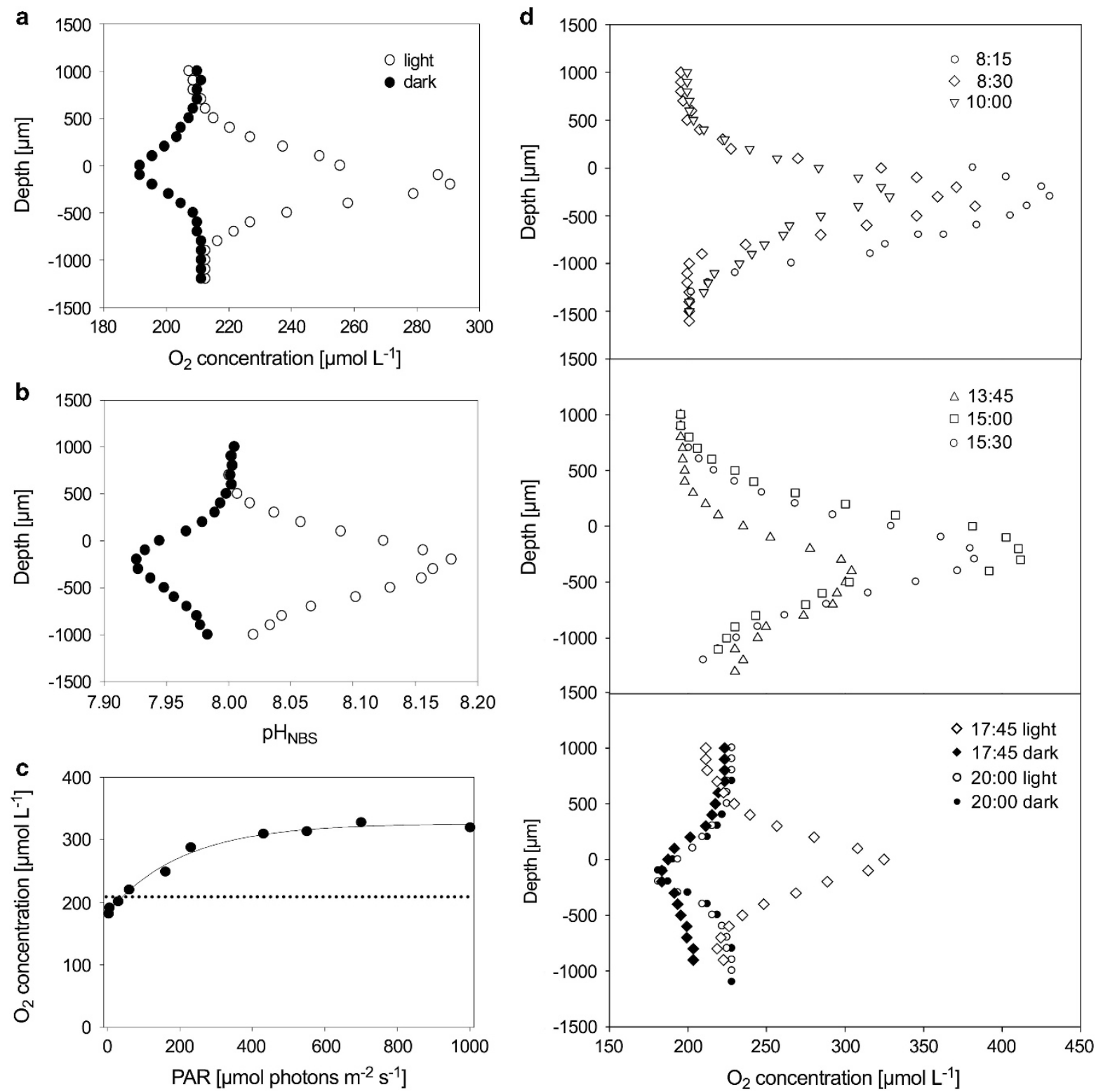

Figure 2 (a, b) Profiles of $\mathrm{O}_{2}$ concentration and $\mathrm{pH}_{\mathrm{NBs}}$ measured in the same Trichodesmium colony in light and dark (measured at 10:00 h). (c) Dependence of $\mathrm{O}_{2}$ concentrations at the surface of a Trichodesmium colony on light intensity (measured at 16:00 h). Dotted line indicates $\mathrm{O}_{2}$ concentration in the ambient water. (d) Profiles of $\mathrm{O}_{2}$ concentrations in Trichodesmium colonies measured at different times of the day in light (open symbols) and dark (closed symbols); each panel shows profiles measured in one colony. The upper colony surface is at $0 \mu \mathrm{m}$ depth.

trichomes, with decreased $\mathrm{C}$ fixation rates (lower by $\sim 15 \%$ ) in cells located in the central part of trichomes compared with the periphery or intermediate regions (Kruskal-Wallis test, $P<0.001$; Supplementary Figure S1). $\mathrm{N}_{2}$ fixation rates were lower by $\sim 50 \%$ in cells located in intermediate areas of the trichomes compared with the central and peripheral regions (Kruskal-Wallis test, $P<0.0001$ ).

C fixation by Trichodesmium during daytime was not affected by an increase in $p \mathrm{CO}_{2}$ (Mann-Whitney test, $P>0.05$; Table 3). For samples measured by LGSIMS, $\mathrm{N}_{2}$ fixation during daytime was significantly elevated in the high $p \mathrm{CO}_{2}$ treatment compared with ambient $p^{2} \mathrm{CO}_{2}$ (Mann-Whitney test, $P<0.0001$;
Table 3). However, this trend was not reflected in the smaller sample size analyzed by nanoSIMS (Table 4). The lower spatial resolution (ca $1 \mu \mathrm{m})$ of the LG-SIMS analyses allows for a greater throughput of measurements than nanoSIMS (ca $100 \mathrm{~nm}$ resolution). Hence, the 117-135 cells analyzed per treatment by LG-SIMS were assumed to be more representative for the population of Trichodesmium cells in these metabolically variable communities than the 28-42 cells analyzed per treatment by nanoSIMS.

Associated bacteria in colonies incubated during daytime were enriched in ${ }^{13} \mathrm{C}$ and ${ }^{15} \mathrm{~N}$, reaching on average $0.06 \pm 0.07 \mathrm{AT} \%$ excess, independent of 


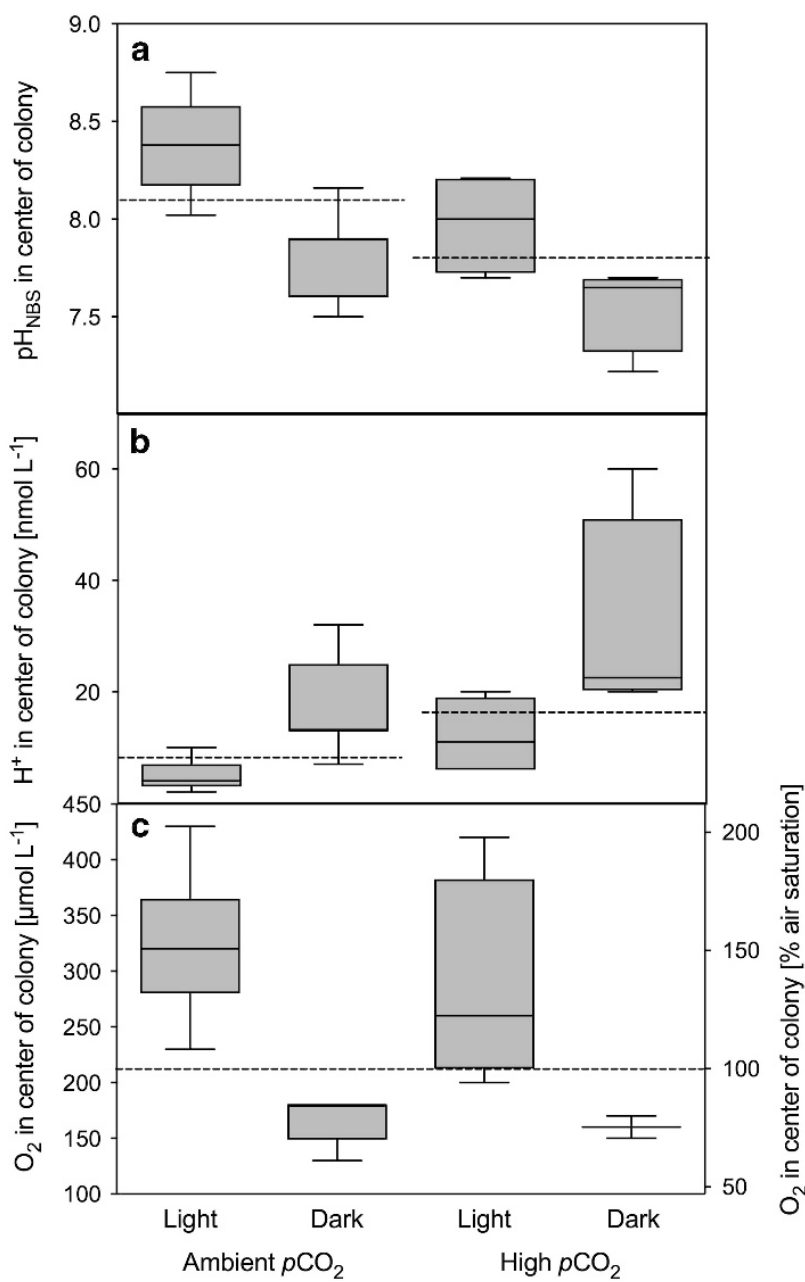

Figure $3 \mathrm{pH}_{\mathrm{NBS}}$ levels (a) as well as proton $\left(\mathrm{H}^{+}\right)$concentrations (b) and $\mathrm{O}_{2}$ concentrations (c) in the center of Trichodesmium colonies measured in light and dark under different $\mathrm{pCO}_{2}$ levels in the surrounding water (ambient vs high $p \mathrm{CO}_{2}$ ). Dashed lines indicate the respective conditions in the ambient water. $n \geqslant 5$, except for $\mathrm{pH}$ and $\mathrm{H}^{+}$at high $p \mathrm{CO}_{2}$ with $n=4$ and $\mathrm{O}_{2}$ at high $\mathrm{CCO}_{2}$ (dark) with $n=3$. Boxes comprise the $25 \%$ and $75 \%$ quartiles; horizontal lines in the center indicate median values; whiskers indicate minimum and maximum values.
$\mathrm{CCO}_{2}$ treatment (Mann-Whitney test, $P>0.05$;

\section{Discussion}

Physiological challenges imposed by $\mathrm{O}_{2}$ and $\mathrm{pH}$ microenvironments

The microsensor measurements revealed elevated $\mathrm{O}_{2}$ concentrations and $\mathrm{pH}$ values within Trichodesmium colonies during the light period caused by photosynthesis. Such conditions in the colony center are disadvantageous for both C-acquisition and $\mathrm{N}_{2}$ fixation. As these conditions do not occur with freeliving trichomes, the benefits of colony formation, which are still unidentified, must exceed the costs incurred by these conditions. It should also be noted that the colonies analyzed in this study were relatively small compared with previous reports (for example, $\sim 450$ trichomes and $12 \mu \mathrm{g}$ POC colony $^{-1}$ (Carpenter et al., 1993); 182 trichomes and $10 \mu \mathrm{g}$ POC colony ${ }^{-1}$ (Letelier and Karl, 1996)), indicating that larger gradients in $\mathrm{O}_{2}$ and $\mathrm{pH}$ are likely to occur.

With specific regard to $\mathrm{O}_{2}$, concentrations measured at the colony surface as a function of light intensity (Figure 2c) indicate that Trichodesmium cells were acclimated to light conditions typical of the upper $10 \mathrm{~m}$ at Station ALOHA (http://hahana.soest.hawaii. edu/hoedylan/data/data.html) and light-saturated, but not photo-inhibited, during $\mathrm{O}_{2}$ measurements performed at $1000 \mu \mathrm{mol}$ photons $\mathrm{m}^{-2} \mathrm{~s}^{-1}$ (light saturation point $\left(\mathrm{I}_{\mathrm{k}}\right) 256 \mu \mathrm{mol}$ photons $\mathrm{m}^{-2} \mathrm{~s}^{-1}$, Figure 2c). The $200 \% \mathrm{O}_{2}$ saturation observed here exceeds previous estimates of $75-100 \%$ saturation (measured at $1140 \mu \mathrm{mol}$ photons $\mathrm{m}^{-2} \mathrm{~s}^{-1}$; Paerl and Bebout, 1988), but is in agreement with estimates of $\sim 150-200 \%$ saturation measured at $<200 \mu \mathrm{mol}$ photons $\mathrm{m}^{-2} \mathrm{~s}^{-1}$ by Prufert-Bebout et al. (1993) and Carpenter et al. (1990). The differences in $\mathrm{O}_{2}$ concentrations may be due to differences in colony size, the biomass and activity of associated bacteria, or the metabolic state of Trichodesmium. One of the prominent temporal

Table 2 Community net $\mathrm{O}_{2}$ production and community dark respiration in Trichodesmium colonies, based on microsensor measurements performed under different $p \mathrm{CO}_{2}$ levels (ambient vs high $p \mathrm{CO}_{2}$; mean \pm s.d.)

\begin{tabular}{|c|c|c|c|c|}
\hline \multirow[t]{2}{*}{$\mathrm{pCO}_{2}$} & \multicolumn{2}{|c|}{ Net $\mathrm{O}_{2}$ production } & \multicolumn{2}{|c|}{ Dark respiration } \\
\hline & nmol $\mathrm{O}_{2}$ colony $^{-1} h^{-1}$ & $\mathrm{nmol} \mathrm{O}_{2} \mathrm{~mm}^{-3} \mathrm{~h}^{-1}$ & ${\text { nmol } \mathrm{O}_{2} \text { colony }}^{-1} \mathrm{~h}^{-1}$ & $\mathrm{nmol} \mathrm{O}_{2} \mathrm{~mm}^{-3} \mathrm{~h}^{-1}$ \\
\hline \multicolumn{5}{|l|}{ Ambient } \\
\hline Mean \pm s.d. & $1.5 \pm 0.9(n=10)$ & $20 \pm 12(n=10)$ & $0.7 \pm 0.4(n=10)$ & $7 \pm 4(n=7)$ \\
\hline Range & $0.4-3.1$ & $3-41$ & $0.3-1.2$ & $2-14$ \\
\hline \multicolumn{5}{|l|}{ High } \\
\hline Mean \pm s.d. & $1.5 \pm 1.7(n=4)$ & $11 \pm 10(n=4)$ & $2.0 \pm 1.9(n=3)$ & $7 \pm 4(n=3)$ \\
\hline Range & $0.2-3.9$ & $4-25$ & $0.4-4.1$ & $3-10$ \\
\hline
\end{tabular}

Abbreviations: $\mathrm{O}_{2}$, oxygen; $p \mathrm{CO}_{2}$, partial pressure of carbon dioxide.

Volumetric rates are normalized to colony volume. 


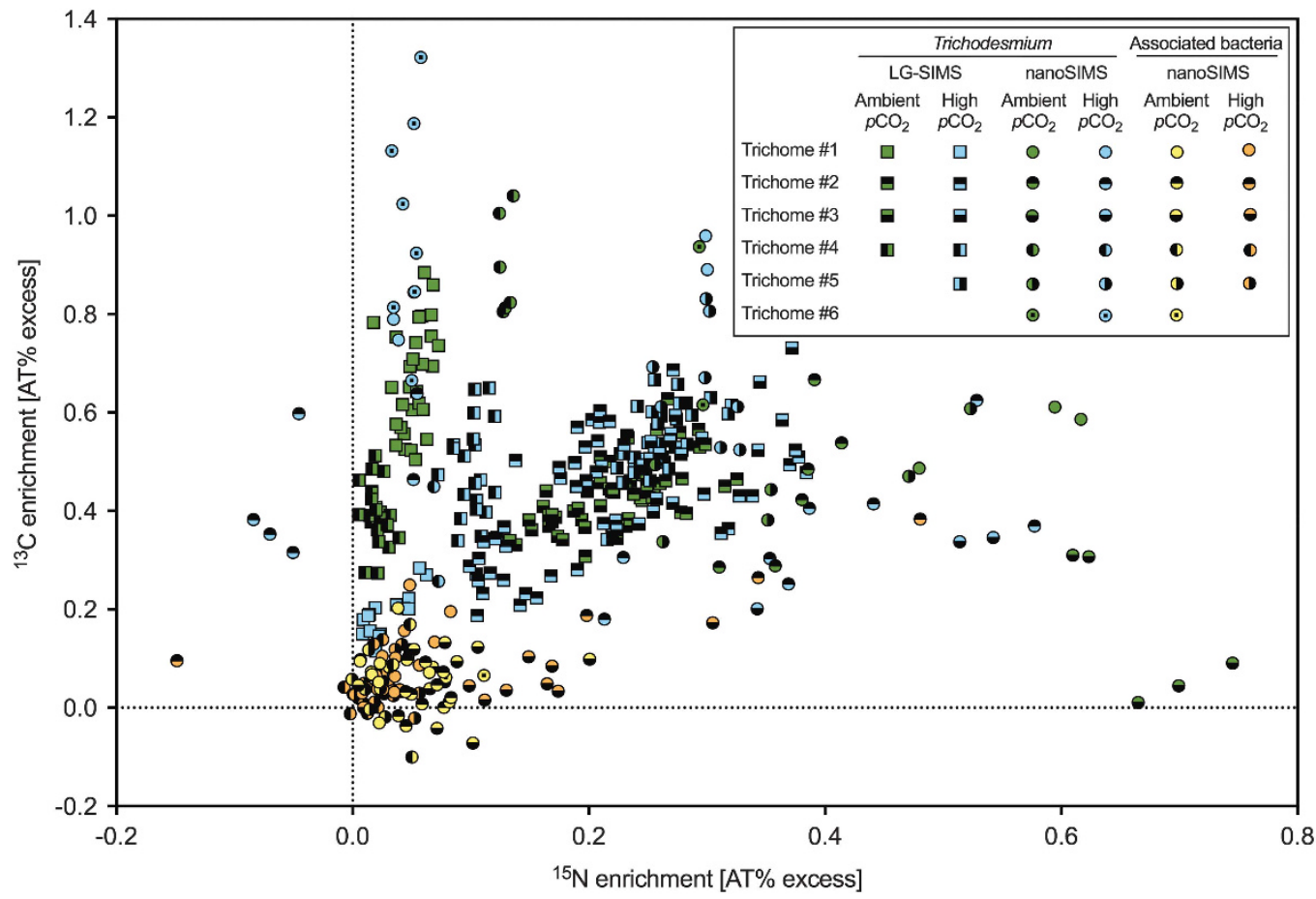

Figure $4{ }^{13} \mathrm{C}$ and ${ }^{15} \mathrm{~N}$ enrichment in individual cells of Trichodesmium and associated bacteria measured by LG-SIMS (squares) and nanoSIMS (circles). Green and blue symbols represent Trichodesmium cells incubated during the day at ambient and high $p \mathrm{CO}_{2}$, respectively; yellow and orange symbols represent associated bacteria incubated during the day at ambient and high $\mathrm{pCO}_{2}$, respectively. Cells located in a single trichome or associated with the same trichome are represented by the same symbol shape and filling.

Table 3 Specific C and N fixation by Trichodesmium incubated at different times of day (day vs night) and under different $p \mathrm{CO}_{2}$ levels (ambient vs high $p \mathrm{CO}_{2}$ ), measured by LG-SIMS (mean \pm s.d.)

\begin{tabular}{|c|c|c|c|}
\hline & $\mathrm{pCO}_{2}$ & $\begin{array}{c}\text { C-specific } C \text { fixation } \\
\left(h^{-1}\right)\end{array}$ & $\begin{array}{c}N \text {-specific } N \text { fixation } \\
\left(h^{-1}\right)\end{array}$ \\
\hline \multirow[t]{2}{*}{ Day } & Ambient & $0.0099 \pm 0.0027$ & $0.0028 \pm 0.0021 \quad(n=117)$ \\
\hline & High & $0.0100 \pm 0.0033$ & $0.0047 \pm 0.0024(n=135)$ \\
\hline \multirow[t]{2}{*}{ Night } & Ambient & $0.0015 \pm 0.0005$ & $0.0004 \pm 0.0001 \quad(n=66)$ \\
\hline & High & $0.0014 \pm 0.0006$ & $0.0004 \pm 0.0002(n=72)$ \\
\hline Contro & & $0.0014 \pm 0.0001$ & $0.0004 \pm 0.0001(n=32)$ \\
\hline
\end{tabular}

Abbreviations: C, carbon; LG-SIMS, large geometry secondary ion mass spectrometry; $\mathrm{N}$, nitrogen; $p \mathrm{CO}_{2}$, partial pressure of carbon dioxide.

Controls are measurements on Trichodesmium cells incubated without stable isotope tracer additions.

variances in $\mathrm{O}_{2}$ concentrations was a midday depression in net $\mathrm{O}_{2}$ production, with $\mathrm{O}_{2}$ saturation decreasing from $190 \%$ to $150 \%$, to reach $<330 \mathrm{~mol} \mathrm{O}_{2} \mathrm{l}^{-1}$ (Figure 2d). In addition, relatively high $\mathrm{O}_{2}$ uptake compared with other colony-forming cyanobacteria (Svedén et al., 2015) was observed, with dark community respiration at $35 \%$ of gross $\mathrm{O}_{2}$ production and a light compensation point (that is, the light intensity at which colony community respiration was balanced by photosynthesis) at $\sim 50 \mu \mathrm{mol}$ photons $\mathrm{m}^{-2} \mathrm{~s}^{-1}$ (Figure 2c), which is in line with previous findings on Trichodesmium (Kana, 1993). These observations suggest that the mechanisms proposed to protect nitrogenase from $\mathrm{O}_{2}$ (Kana, 1993; Berman-Frank et al., 2001) were active; however, $\mathrm{O}_{2}$ concentrations in the colony microenvironment were still elevated substantially above ambient concentrations throughout the day (Figure 2d). Anoxia has been observed within heterotrophic, suspended microbial aggregates exceeding $1 \mathrm{~mm}$ in diameter (Ploug et al., 1997; Klawonn et al., 2015a), whereas photosynthetically active aggregates of heterocystous cyanobacteria showed elevated $\mathrm{O}_{2}$ concentrations, in agreement with our study (Ploug, 2008). In Trichodesmium, which lacks the diffusion barrier provided by heterocysts, intracellular biochemical or physiological mechanisms (for example, respiration and Mehler reaction; Milligan et al., 2007) are required to reduce $\mathrm{O}_{2}$ concentrations in the vicinity of nitrogenase. The resulting intracellular $\mathrm{O}_{2}$ gradients may differ on a single-cell level depending on cell specialization (diazocytes vs vegetative cells).

The elevated $\mathrm{pH}$ levels in the colony microenvironment suggest reduced $\mathrm{CO}_{2}$ concentrations because of photosynthetic C uptake. RubisCO in cyanobacteria has an especially low affinity for $\mathrm{CO}_{2}$ (Badger et al., 1998), and Trichodesmium has been shown to compensate for this by highly active $\mathrm{C}$ concentrating mechanisms (CCM's; for example, Kranz et al., 2009). Although $>80 \%$ of $\mathrm{C}$ uptake by Trichodesmium was found to be met by uptake of $\mathrm{HCO}_{3}^{-}$(Kranz et al., 2009; Eichner et al., 2015), previous studies showed notable responses in CCM activity to changes in $p \mathrm{CO}_{2}$ (for example, twofold lower DIC half saturation concentrations in cells acclimated to $150 \mathrm{ppm} p \mathrm{CO}_{2}\left(\mathrm{pH}_{\mathrm{NBS}}\right.$ 8.56) compared with $370 \mathrm{ppm}$ $\left(\mathrm{pH}_{\mathrm{NBS}}\right.$ 8.26); Kranz et al., 2009). Also elevated $\mathrm{O}_{2}$ 
Table $4{ }^{13} \mathrm{C}$ and ${ }^{15} \mathrm{~N}$ enrichment in Trichodesmium and associated bacteria measured by nanoSIMS after 12 -h incubations with $\mathrm{NaH}^{13} \mathrm{CO}_{3}$ (AT\% excess of $4.2 \pm 0.2$ (ambient $p \mathrm{CO}_{2}$ ) and $3.8 \pm 0.1$ (high $\left.p \mathrm{CO}_{2}\right)$ ) and ${ }^{15} \mathrm{~N}_{2}\left(\mathrm{AT} \%\right.$ excess of $4.2 \pm 0.4$ (ambient $p \mathrm{CO}_{2}$ ) and $3.5 \pm 0.3($ high $\left.p \mathrm{CO}_{2}\right)$ ) at different times (day vs night) and under different $p \mathrm{CO}_{2}$ levels (ambient vs high $p \mathrm{CO}_{2} ;$ mean \pm s.d.)

\begin{tabular}{|c|c|c|c|c|c|}
\hline & \multirow[t]{2}{*}{$p C O_{2}$} & \multicolumn{2}{|c|}{ Trichodesmium } & \multicolumn{2}{|c|}{ Associated bacteria } \\
\hline & & $\begin{array}{c}{ }^{13} \mathrm{C} \text { enrichment } \\
\text { (AT\% excess) }\end{array}$ & $\begin{array}{c}{ }^{15} \mathrm{~N} \text { enrichment } \\
\text { (AT\% excess) }\end{array}$ & $\begin{array}{c}{ }^{13} \mathrm{C} \text { enrichment } \\
\text { (AT\% excess) }\end{array}$ & $\begin{array}{c}{ }^{15} \mathrm{~N} \text { enrichment } \\
\text { (AT\% excess) }\end{array}$ \\
\hline \multirow[t]{2}{*}{ Day } & Ambient & $0.53 \pm 0.28(n=28)$ & $0.39 \pm 0.19(n=28)$ & $0.06 \pm 0.06(n=51)$ & $0.05 \pm 0.04(n=60)$ \\
\hline & High & $0.56 \pm 0.26(n=40)$ & $0.21 \pm 0.19(n=42)$ & $0.07 \pm 0.07(n=62)$ & $0.06 \pm 0.09(n=65)$ \\
\hline Night & $\begin{array}{l}\text { Ambient } \\
\text { High }\end{array}$ & $\begin{array}{c}\text { ND } \\
-0.02 \pm 0.02(n=4)\end{array}$ & $\begin{array}{c}\text { ND } \\
0.01 \pm 0.00(n=4)\end{array}$ & $\begin{array}{l}\text { ND } \\
-0.02 \pm 0.06(n=30)\end{array}$ & $\begin{array}{l}\text { ND } \\
0.01 \pm 0.01(n=40)\end{array}$ \\
\hline
\end{tabular}

Abbreviations: AT\% excess, atom percent excess; C, carbon; N, nitrogen; nanoSIMS, nanoscale secondary ion mass spectrometry; ND, not determined; $p \mathrm{CO}_{2}$, partial pressure of carbon dioxide.

concentrations in the colony microenvironment may affect the CCM by increasing the risk for photorespiration: kinetic properties of RubisCO (Badger et al., 1998) suggest up to $18 \%$ lower $\mathrm{C}$ fixation rates under $\mathrm{O}_{2}$ concentrations measured in the colony center. Our findings thus indicate that cells have to compensate for the low $\mathrm{CO}_{2}$ availability and high $\mathrm{O}_{2}$ concentrations in colonies, by investing more energy into the CCM to maintain similar $\mathrm{C}$ fixation rates as free-living trichomes.

\section{$\mathrm{C}$ and $\mathrm{N}_{2}$ fixation and cellular interactions in}

Trichodesmium colonies

SIMS revealed a remarkably high variability in $\mathrm{C}$ and $\mathrm{N}_{2}$ fixation between single cells, including trichomes that were photosynthetically active, but acquired no or little $\mathrm{N}$ by $\mathrm{N}_{2}$ fixation (or uptake of newly fixed $\mathrm{N}$ released by other trichomes in the colony). A similar pattern, with only half of the photosynthetically active Trichodesmium cells actively fixing $\mathrm{N}_{2}$, was recently observed in the tropical North Atlantic (Martínez-Pérez et al., 2016). In contrast to previous studies demonstrating species-specific differences in $\mathrm{N}_{2}$ fixation (Carpenter et al., 1993) and substantial variability in community-level $\mathrm{C}: \mathrm{N}$ fixation ratios across studies (Mulholland et al., 2006), this high variability could not be explained by species identity or by differences in experimental conditions. Different $\mathrm{N}$ acquisition strategies, as well as differences in storage metabolism, which could cause an uncoupling of $\mathrm{C}$ and $\mathrm{N}$ fluxes during the incubation period (Finzi-Hart et al., 2009), may account for some of this variation. Whereas $\mathrm{N}$ transfer between diazocytes and vegetative cells in Trichodesmium is commonly assumed to rely on extracellular diffusion (Mulholland and Capone, 2000), intercellular metabolite exchange via septal junctions was recently demonstrated in heterocystous cyanobacteria (Nürnberg et al., 2015). Our observation that trichomes differed more strongly from each other than cells within the same trichome (Figure 4) indicates that $\mathrm{N}$ and $\mathrm{C}$ were transferred more efficiently along single trichomes than between different trichomes. Therefore, we hypothesize that Trichodesmium may have direct intercellular transport mechanisms similar to heterocystous cyanobacteria, which have not been described for this species.

The potential to separate $\mathrm{N}_{2}$ fixation from photosynthesis in space or time has been a debated topic in Trichodesmium ecology. The majority of cells $(\sim 75 \%)$ in our study was enriched in both ${ }^{13} \mathrm{C}$ and ${ }^{15} \mathrm{~N}$ after 12 -h incubations, consistent with findings by Finzi-Hart et al. (2009), and supporting the perspective that fixation and intercellular transport of $\mathrm{C}$ and $\mathrm{N}$ are regulated on shorter time scales (Küpper et al., 2004; Popa et al., 2007). The differences in $\mathrm{C}$ and $\mathrm{N}_{2}$ fixation between cells depending on their location (Supplementary Figure S1) indicate some degree of cell specialization along trichomes, consistent with the concept of diazocytes (Bergman and Carpenter, 1991; BermanFrank et al., 2001). The $\mathrm{O}_{2}$ and $\mathrm{pH}$ gradients causing adverse conditions for both $\mathrm{C}$ and $\mathrm{N}_{2}$ fixation in the colony center question the proposed spatial separation on a colony level (Paerl, 1994).

The ${ }^{15} \mathrm{~N}$ enrichment of associated bacteria in the colonies indicates that they assimilated newly fixed ${ }^{15} \mathrm{~N}$ released by Trichodesmium, in agreement with findings from a recent study in the South West Pacific (Bonnet et al., 2016). Presumably, the ${ }^{15} \mathrm{~N}$-enriched associated bacteria did not include single-celled $\mathrm{N}_{2}$-fixing cyanobacteria, as they showed neither chl $a$ autofluorescence nor ${ }^{15} \mathrm{~N}$ enrichment during night incubations. Moreover, no autotrophic host cells (as expected for nonautotrophic cyanobacteria such as UCYN-A; Thompson et al., 2012) were observed. The associated bacteria are also unlikely to be heterotrophic $\mathrm{N}_{2}$-fixers as the ${ }^{15} \mathrm{~N}$ enrichment was restricted to the daytime when Trichodesmium fixed $\mathrm{N}_{2}$ (Table 4), whereas heterotrophic $\mathrm{N}_{2}$-fixers have been found to express nifH equally or at stronger levels at night-time compared with daytime (Church et al., 2005; Moisander et al., 2014). Enrichment of these non-photosynthetic bacteria in ${ }^{13} \mathrm{C}$, in addition to ${ }^{15} \mathrm{~N}$, points toward transfer of $\mathrm{C}$ and $\mathrm{N}$ from Trichodesmium in the form of dissolved organic $\mathrm{C}$ and/or $\mathrm{N}$, in line with previous reports on amino-acid release by Trichodesmium (Mulholland and Capone, 2000). Trichodesmium is also a source of transparent exopolymer particles, 
which can form mucoid sheaths around trichomes (observed in our samples by scanning electron microscopy) and provide a colonization matrix for heterotrophic bacteria (Sheridan et al., 2002; Berman-Frank et al., 2007).

C- and N-based generation times for Trichodesmium were relatively long (5-28 days), in agreement with previous studies (LaRoche and Breitbarth, 2005; Mulholland et al., 2006). In addition to large-scale nutrient patterns and loss processes in the water column, microenvironments may have an important role in determining Trichodesmium growth, with elevated $\mathrm{pH}$ and $\mathrm{O}_{2}$ posing physiological constraints to $\mathrm{C}$ acquisition and $\mathrm{N}_{2}$ fixation and influencing the availability of iron and phosphorus within colonies.

\section{Implications for ocean acidification responses}

The lack of $\mathrm{CO}_{2}$-responses in $\mathrm{O}_{2}$ evolution (observed by microsensors) and the positive effect of elevated $p \mathrm{CO}_{2}$ on $\mathrm{N}_{2}$ fixation (observed by LG-SIMS) are in agreement with several previous studies, including laboratory studies on Trichodesmium grown in single trichomes (for example, Hutchins et al., 2007; Levitan et al., 2007; Kranz et al., 2010a) and field studies on Trichodesmium colonies (Hutchins et al., 2009; Lomas et al., 2012). Other recent field studies, in contrast, showed no or variable $\mathrm{CO}_{2}$ effects on $\mathrm{C}$ and $\mathrm{N}_{2}$ fixation (Law et al., 2012; Böttjer et al., 2014; Gradoville et al., 2014), highlighting the variability in $\mathrm{CO}_{2}$ responses of Trichodesmium.

Trichodesmium in the field is adapted to highly variable $\mathrm{O}_{2}$ and $\mathrm{pH}$ levels within the colony microenvironment, with the magnitude of diurnal $\mathrm{pH}$ variations ( 0.5 units) exceeding that of ocean acidification effects expected until the end of the century in the ambient seawater $(0.3 \mathrm{pH}$ units for RCP8.5; IPCC, 2013). The adaptation to high short-term $\mathrm{pH}$ variability may decrease the sensitivity of Trichodesmium colonies to the long-term trend of ocean acidification, yet the importance of the different time scales of these concurrent processes for cellular physiology is not well understood. In contrast, the energy dependence of $\mathrm{CO}_{2}$ responses in Trichodesmium (for example, Kranz et al., 2010a; Eichner et al., 2014) suggests that the energy demands imposed by high CCM activity and $\mathrm{O}_{2}$ protection of nitrogenase in colonies may enhance $\mathrm{CO}_{2}$ effects, especially under low light intensities. Considering the species-specific differences in $\mathrm{CO}_{2}$ sensitivity of Trichodesmium (Hutchins et al., 2013), the species diversity and differences in metabolic activity between trichomes observed here seem likely to cause variable $\mathrm{CO}_{2}$ responses. Differential $\mathrm{CO}_{2}$ responses of Trichodesmium species and their associated bacteria, in turn, will affect the microbial interactions within colonies under ocean acidification.

\section{Conclusion and outlook}

In summary, Trichodesmium colonies were characterized by substantial gradients in $\mathrm{O}_{2}$ concentrations and $\mathrm{pH}$ on a micrometer scale. In addition, the large range in $\mathrm{O}_{2}$ and $\mathrm{pH}$ levels observed in light vs dark conditions suggests vast changes over daynight cycles. In an oligotrophic region often considered relatively stable, colonies thus provide variable microenvironments, requiring pronounced physiological flexibility in Trichodesmium and its associated organisms. The high diversity in $\mathrm{C}$ and $\mathrm{N}$ uptake rates at a single-cell level may be an adaptation of these microbial populations to thrive in fluctuating microenvironments. Future studies should address the mechanisms of $\mathrm{C}$ and $\mathrm{N}_{2}$ fixation under the adverse conditions in the colony microenvironment, as well as the benefits of colony formation, the mechanisms of $\mathrm{N}$ transport between Trichodesmium cells, and the implications of different time scales in carbonate chemistry variability.

\section{Conflict of Interest}

The authors declare no conflict of interest.

\section{Acknowledgements}

This work was supported by the Alexander von Humboldt Foundation, The Swedish Research Council for Environment, Agricultural Sciences and Planning (FORMAS grant no. 215-2010-779 to HP), the University of Gothenburg, the Max Planck Society and the Daniel K Inouye Center for Microbial Oceanography: Research and Education (C-MORE). C-MORE and the Hawaii Ocean Time-series (HOT) are funded by the National Science Foundation (EF-0424599 and OCE-1260164, respectively). Additional support was provided by the Gordon and Betty Moore Foundation (DMK, \#3794) and the Simons Foundation (SCOPE Award ID 329108, DMK). Nordsim operates as a national infrastructure supported by the Swedish Research Council (grant no. 821-20146375); this is Nordsim publication \#501. We thank the crew of R/V Kilo Moana, especially the Ocean Technology Group technicians, chief scientist Fernando Santiago-Mandujano and the HOT team for their excellent support during the cruise. We are also grateful to Christopher Schvarcz for assistance in colony sampling, Daniela Tienken and Niels Schoffelen for excellent support with nanoSIMS sample preparation and measurements, Lev Ilyinsky and Kerstin Lindén for LG-SIMS measurements, and Björn Rost and Laura Wischnewsky for TA and DIC measurements.

\section{References}

Badger MR, Andrews TJ, Whitney SM, Ludwig M, Yellowlees DC, Leggat W et al. (1998). The diversity and coevolution of Rubisco, plastids, pyrenoids, and chloroplast-based $\mathrm{CO}_{2}$-concentrating mechanisms in algae. Can J Bot 76: 1052-1071. 
Bergman B, Carpenter EJ. (1991). Nitrogenase confined to randomly distributed trichomes in the marine cyanobacterium Trichodesmium thiebautii. J Phycol 27: 158-165.

Bergman B, Sandh G, Lin S, Larsson J, Carpenter EJ. (2013). Trichodesmium - a widespread marine cyanobacterium with unusual nitrogen fixation properties. FEMS Microbiol Rev 37: 286-302.

Berman-Frank I, Lundgren P, Chen YB, Küpper H, Kolber Z, Bergman B et al. (2001). Segregation of nitrogen fixation and oxygenic photosynthesis in the marine cyanobacterium Trichodesmium. Science 294: 1534-1537.

Berman-Frank I, Rosenberg G, Levitan O, Haramaty L, Mari X. (2007). Coupling between autocatalytic cell death and transparent exopolymeric particle production in the marine cyanobacterium Trichodesmium. Environ Microbiol 9: 1415-1422.

Bonnet S, Berthelot H, Turk-Kubo K, Cornet-Barthaux V, Fawcett S, Berman-Frank I et al. (2016). Diazotroph derived nitrogen supports diatom growth in the South West Pacific: a quantitative study using nanoSIMS. Limnol Oceanogr 61: 1549-1562.

Böttjer D, Dore JE, Karl DM, Letelier RM, Mahaffey C, Wilson ST et al. (2017). Temporal variability of nitrogen fixation and particulate nitrogen export at Station ALOHA. Limnol Oceanogr 62: 200-216.

Böttjer D, Karl DM, Letelier RM, Viviani DA, Church MJ. (2014). Experimental assessment of diazotroph responses to elevated seawater $\mathrm{pCO}_{2}$ in the North Pacific Subtropical Gyre. Glob Biogeochem Cyc 28: 601-616.

Broecker WS, Peng TH. (1974). Gas exchange rates between air and sea. Tellus 26: 21-35.

Burgess BK, Lowe DJ. (1996). Mechanism of molybdenum nitrogenase. Chem Rev 96: 2983-3012.

Carpenter EJ, Chang J, Cottrell M, Schubauer J, Paerl HW, Bebout BM et al. (1990). Reevaluation of nitrogenase oxygen-protective mechanisms in the planktonic marine cyanobacterium Trichodesmium. Mar Ecol Prog Ser 65: 151-158.

Carpenter EJ, ONeil JM, Dawson R, Capone DG, Siddiqui PJA, Roenneberg $\mathrm{T}$ et al. (1993). The tropical diazotrophic phytoplankter Trichodesmium - biological characteristics of two common species. Mar Ecol Prog Ser 95: 295-304.

Carpenter EJ, Price C. (1976). Marine Oscillatoria (Trichodesmium): explanation for aerobic nitrogen fixation without heterocysts. Science 191: 1278-1280.

Carpenter EJ, Subramaniam A, Capone DG. (2004). Biomass and primary productivity of the cyanobacterium Trichodesmium spp. in the tropical N Atlantic ocean. Deep-Sea Res Pt I 51: 173-203.

Church MJ, Short CM, Jenkins BD, Karl DM, Zehr JP. (2005). Temporal patterns of nitrogenase gene (nifH) expression in the oligotrophic North Pacific Ocean. Appl Environ Microbiol 71: 5362-5370.

Dore JE, Brum JR, Tupas LM, Karl DM. (2002). Seasonal and interannual variability in sources of nitrogen supporting export in the oligotrophic subtropical North Pacific Ocean. Limnol Oceanogr 47: 1595-1607.

Durner J, Böhm I, Knörzer OC, Böger P. (1996). Proteolytic degradation of dinitrogenase reductase from Anabaena variabilis (ATCC 29413) as a consequence of ATP depletion and impact of oxygen. J Bacteriol 178: 606-610.
Eichner M, Kranz SA, Rost B. (2014). Combined effects of different $\mathrm{CO}_{2}$ levels and $\mathrm{N}$ sources on the diazotrophic cyanobacterium Trichodesmium. Phys Plant 152: 316-330.

Eichner M, Thoms S, Kranz SA, Rost B. (2015). Cellular inorganic carbon fluxes in Trichodesmium: a combined approach using measurements and modelling. J Exp Bot 66: 749-759.

Finzi-Hart JA, Pett-Ridge J, Weber PK, Popa R, Fallon SJ, Gunderson T et al. (2009). Fixation and fate of C and N in the cyanobacterium Trichodesmium using nanometer-scale secondary ion mass spectrometry. Proc Nat Acad Sci USA 106: 6345-6350.

Flynn KJ, Blackford JC, Baird ME, Raven JA, Clark DR, Beardall J et al. (2012). Changes in $\mathrm{pH}$ at the exterior surface of plankton with ocean acidification. Nat Clim Change 2: 510-513.

Fredriksson C, Bergman B. (1995). Nitrogenase quantity varies diurnally in a subset of cells within colonies of the non-heterocystous cyanobacteria Trichodesmium spp. Microbiol 141: 2471-2478.

Gallon JR. (1992). Reconciling the incompatible: $\mathrm{N}_{2}$ fixation and $\mathrm{O}_{2}$. New Phytol 122: 571-609.

Gradoville MR, White AE, Böttjer D, Church MJ, Letelier RM. (2014). Diversity trumps acidification: lack of evidence for carbon dioxide enhancement of Trichodesmium community nitrogen or carbon fixation at Station ALOHA. Limnol Oceanogr 59: 645-659.

Hewson I, Poretsky RS, Dyhrman ST, Zielinski B, White AE, Tripp HJ et al. (2009). Microbial community gene expression within colonies of the diazotroph, Trichodesmium, from the Southwest Pacific Ocean. ISME J 3: 1286-1300.

Hmelo LR, Van Mooy BAS, Mincer TJ. (2012). Characterization of bacterial epibionts on the cyanobacterium Trichodesmium. Aquat Microb Ecol 67: 1-14.

Hutchins DA, Fu FX, Webb EA, Walworth N, Tagliabue A. (2013). Taxon-specific response of marine nitrogen fixers to elevated carbon dioxide concentrations. Nat Geosci 6: 790-795.

Hutchins DA, Fu FX, Zhang Y, Warner ME, Feng Y, Portune $\mathrm{K}$ et al. (2007). $\mathrm{CO}_{2}$ control of Trichodesmium $\mathrm{N}_{2}$ fixation, photosynthesis, growth rates, and elemental ratios: implications for past, present, and future ocean biogeochemistry. Limnol Oceanogr 52: 1293-1304.

Hutchins DA, Mulholland MR, Fu F. (2009). Nutrient cycles and marine microbes in a $\mathrm{CO}_{2}$-enriched ocean. Oceanography 22: 128-145.

Hynes AM, Webb EA, Doney SC, Waterbury JB. (2012). Comparison of cultured Trichodesmium (cyanophyceae) with species characterized from the field. J Phycol 48: 196-210.

IPCC. (2013). Summary for Policymakers. In: Stocker TF, Qin D, Plattner G-K, Tignor M, Allen SK, Boschung J et al. (eds.) Climate Change 2013: The Physical Science Basis. Contribution of Working Group I to the Fifth Assessment Report of the Intergovernmental Panel on Climate Change. Cambridge University Press: Cambridge, UK and New York, NY, USA, pp 3-29.

Jørgensen BB, Revsbech NP. (1985). Diffusive boundary layers and the oxygen uptake of sediments and detritus. Limnol Oceanogr 30: 111-112.

Kana TM. (1993). Rapid oxygen cycling in Trichodesmium thiebautii. Limnol Oceanogr 38: 18-24.

Karl DM, Bidigare RR, Church MJ, Dore JE, Letelier RM, Mahaffey C et al. (2008). The nitrogen cycle in the 
North Pacific trades biome: an evolving paradigm. In: Capone DG, Bronk DA, Mulholland MR, Carpenter E (eds). Nitrogen in the Marine Environment 2nd edn. Academic Press: San Diego, CA, USA, pp 705-769.

Karl DM, Letelier R, Hebel DV, Bird DF, Winn CD. (1992). Trichodesmium blooms and new nitrogen in the North Pacific gyre. In: Carpenter EJ, Capone DG (eds). Marine Pelagic Cyanobacteria: Trichodesmium and Other Diazotrophs. Springer Netherlands: Dordrecht, The Netherlands, pp 219-237.

Karl D, Letelier R, Tupas L, Dore J, Christian J, Hebel D. (1997). The role of nitrogen fixation in biogeochemical cycling in the subtropical North Pacific Ocean. Nature 388: $533-538$.

Klawonn I, Bonaglia S, Brüchert V, Ploug H. (2015a). Aerobic and anaerobic nitrogen transformation processes in $\mathrm{N}_{2}$-fixing cyanobacterial aggregates. ISME J 9: 1456-1466.

Klawonn I, Lavik G, Böning P, Marchant HK, Dekaezemacker J, Mohr W et al. (2015b). Simple approach for the preparation of ${ }^{15-15} \mathrm{~N}_{2}$-enriched water for nitrogen fixation assessments: evaluation, application and recommendations. Frontiers Microbiol 6: 769.

Kranz S, Sültemeyer D, Richter KU, Rost B. (2009). Carbon acquisition by Trichodesmium: the effect of $\mathrm{pCO}_{2}$ and diurnal changes. Limnol Oceanogr 54: $548-559$

Kranz SA, Levitan O, Richter KU, Prášil O, Berman-Frank I, Rost B. (2010a). Combined effects of $\mathrm{CO}_{2}$ and light on the $\mathrm{N}_{2}$-fixing cyanobacterium Trichodesmium IMS101: physiological responses. Plant Phys 154: 334-345.

Kranz SA, Wolf-Gladrow D, Nehrke G, Langer G, Rost B. (2010b). Calcium carbonate precipitation induced by the growth of the marine cyanobacteria Trichodesmium. Limnol Oceanogr 55: 2563-2569.

Küpper H, Ferimazova N, Setlík I, Berman-Frank I. (2004). Traffic lights in Trichodesmium. Regulation of photosynthesis for nitrogen fixation studied by chlorophyll fluorescence kinetic microscopy. Plant Phys 135: 2120-2133.

LaRoche J, Breitbarth E. (2005). Importance of the diazotrophs as a source of new nitrogen in the ocean. J Sea Res 53: 67-91.

Law CS, Breitbarth E, Hoffmann LJ, McGraw CM, Langlois RJ, LaRoche J et al. (2012). No stimulation of nitrogen fixation by non-filamentous diazotrophs under elevated $\mathrm{CO}_{2}$ in the South Pacific. Glob Change Biol 18: 3004-3014.

Letelier RM, Karl DM. (1996). Role of Trichodesmium spp. in the productivity of the subtropical North Pacific Ocean. Mar Ecol Prog Ser 133: 263-273.

Levitan O, Rosenberg G, Setlik I, Setlikova E, Grigel J, Klepetar J et al. (2007). Elevated $\mathrm{CO}_{2}$ enhances nitrogen fixation and growth in the marine cyanobacterium Trichodesmium. Glob Change Biol 13: 531-538.

Lomas MW, Hopkinson BM, Losh JL, Ryan DE, Shi DL, $\mathrm{Xu} \mathrm{Y}$ et al. (2012). Effect of ocean acidification on cyanobacteria in the subtropical North Atlantic. Aquat Microb Ecol 66: 211-222.

Martínez-Pérez C, Mohr W, Löscher C, Dekaezemacker J, Littmann S, Yilmaz $\mathrm{P}$ et al. (2016). The small unicellular diazotrophic symbiont, UCYN-A, is a key player in the marine nitrogen cycle. Nat Microbiol 1: 16163.
Milligan AJ, Berman-Frank I, Gerchman Y, Dismukes GC Falkowski PG. (2007). Light-dependent oxygen consumption in nitrogen-fixing cyanobacteria plays a key role in nitrogenase protection. J Phycol 43: 845-852.

Momper LM, Reese BK, Carvalho G, Lee P, Webb EA. (2015). A novel cohabitation between two diazotrophic cyanobacteria in the oligotrophic ocean. ISME $J$ 9: 882-893.

Montoya JP, Voss M, Kahler P, Capone DG. (1996). A simple, high-precision, high-sensitivity tracer assay for $\mathrm{N}_{2}$ fixation. Appl Environ Microbiol 62: 986-993.

Moisander PH, Serros T, Paerl RW, Beinart RA, Zehr JP. (2014). Gammaproteobacterial diazotrophs and nifH gene expression in surface waters of the South Pacific Ocean. ISME J 8: 1962-1973.

Mulholland MR. (2007). The fate of nitrogen fixed by diazotrophs in the ocean. Biogeosciences 4: 37-51.

Mulholland MR, Bernhardt PW, Heil CA, Bronk DA, O’Neil JM. (2006). Nitrogen fixation and release of fixed nitrogen by Trichodesmium spp. in the Gulf of Mexico. Limnol Oceanogr 51: 1762-1776.

Mulholland MR, Capone DG. (2000). The nitrogen physiology of the marine $\mathrm{N}_{2}$-fixing cyanobacteria Trichodesmium spp. Trends Plant Sci 5: 148-153.

Nürnberg DJ, Mariscal V, Bornikoel J, Nieves-Morión M, Krauß N, Herrero A et al. (2015). Intercellular diffusion of a fluorescent sucrose analog via the septal junctions in a filamentous cyanobacterium. MBio 6: e02109-e02114.

Paerl HW. (1994). Spatial segregation of $\mathrm{CO}_{2}$ fixation in Trichodesmium spp: linkage to $\mathrm{N}_{2}$ fixation potential. I Phycol 30: 790-799.

Paerl HW, Bebout BM. (1988). Direct measurement of $\mathrm{O}_{2}$ depleted microzones in marine Oscillatoria: relation to $\mathrm{N}_{2}$ fixation. Science 241: 442-445.

Ploug H. (2008). Cyanobacterial surface blooms formed by Aphanizomenon sp. and Nodularia spumigena in the Baltic Sea: small-scale fluxes, $\mathrm{pH}$, and oxygen microenvironments. Limnol Oceanogr 53: 914-921.

Ploug H, Jørgensen BB. (1999). A net-jet flow system for mass transfer and microsensor studies of sinking aggregates. Mar Ecol Prog Ser 176: 279-290.

Ploug H, Kühl M, Buchholz-Cleven B, Jørgensen BB. (1997). Anoxic aggregates-an ephemeral phenomenon in the pelagic environment? Aqua Microbial Ecol 13: 285-294.

Polerecky L, Adam B, Milucka J, Musat N, Vagner T, Kuypers MM. (2012). Look@NanoSIMS-a tool for the analysis of nanoSIMS data in environmental microbiology. Environ Microbiol 14: 1009-1023.

Popa R, Weber PK, Pett-Ridge J, Finzi JA, Fallon SJ, Hutcheon ID et al. (2007). Carbon and nitrogen fixation and metabolite exchange in and between individual cells of Anabaena oscillarioides. ISME J 1: 354-360.

Prufert-Bebout L, Paerl HW, Lassen C. (1993). Growth, nitrogen fixation, and spectral attenuation in cultivated Trichodesmium species. Appl Environ Microbiol 59: 1367-1375.

Sheridan CC, Steinberg DK, Kling GW. (2002). The microbial and metazoan community associated with colonies of Trichodesmium spp.: a quantitative survey. J Plankton Res 24: 913-922.

Shi D, Kranz SA, Kim JM, Morel FM. (2012). Ocean acidification slows nitrogen fixation and growth in the dominant diazotroph Trichodesmium under low-iron conditions. Proc Nat Acad Sci USA 109: E3094-E3100. 
Siddiqui PJA, Bergman B, Carpenter EJ. (1992). Filamentous cyanobacterial associates of the marine planktonic cyanobacterium Trichodesmium. Phycologia 31: 326-337.

Staal M, Rabouille S, Stal LJ. (2007). On the role of oxygen for nitrogen fixation in the marine cyanobacterium Trichodesmium sp. Environ Microbiol 9: 727-736.

Strickland JDH, Parsons TR. (1972). A Practical Handbook of Seawater Analysis. Fisheries Research Board of Canada, Ottawa, Ontario.

Svedén JB, Adam B, Walve J, Nahar N, Musat N, Lavik G et al. (2015). High cell-specific rates of nitrogen and carbon fixation by the cyanobacterium Aphanizomenon sp. at low temperatures in the Baltic Sea. FEMS Microbiol Ecol 91: fiv131.

Thompson AW, Foster RA, Krupke A, Carter BJ, Musat N, Vaulot D et al. (2012). Unicellular cyanobacterium symbiotic with a single-celled eukaryotic alga. Science 337: 1546-1550.
Wolf-Gladrow DA, Bijma J, Zeebe RE. (1999). Model simulation of the carbonate chemistry in the microenvironment of symbiont bearing foraminifera. Mar Chem 64: 181-198.

cc)(i)(2) This work is licensed under a Creative Commons Attribution-NonCommercialShareAlike 4.0 International License. The images or other third party material in this article are included in the article's Creative Commons license, unless indicated otherwise in the credit line; if the material is not included under the Creative Commons license, users will need to obtain permission from the license holder to reproduce the material. To view a copy of this license, visit http:/creativecommons.org/ licenses/by-nc-sa/4.0/

(c) The Author(s) 2017

Supplementary Information accompanies this paper on The ISME Journal website (http://www.nature.com/ismej) 